\title{
ПІДВИЩЕННЯ КВАЛІФІКАЦІЇ ВЧИТЕЛІВ У СФЕРІ ІНТЕЛЕКТУАЛЬНОЇ ВЛАСНОСТІ В УМОВАХ ДИВЕРСИФІКАЦІЇ ОСВІТНІХ ПОСЛУГ
}

У статті розглянуто проблеми, пов'язані з динамікою надання освітніх послуг із диверсифікаиіi у ході підвищення кваліфікаиї педагогічних кадрів в Україні, щзо обумовлено дією Закону Украӥни «Про освіту» та постановою Кабінету Міністрів України "Деякі питання підвищення кваліфікаџї̈ педагогічних і науково-педагогічних працівників». Оприлюднено результати дослідження, проведеного на прикладі конкретної адміністративної одиниці - Основ'янського району м. Харкова. Обгрунтовано важливість створення окремих модулів у межах 30 годин (1 кредиту) для формування певних спечіальних компетентностей працівників освіти за результатами самооиінювання.

Ключові слова: диверсифікачія освітніх послуг, керівник освіти, змістовий модуль, працівник освіти, учитель, заклад вищої освіти, заклад загальної середньої освіти, підвищення кваліфікації.

В статье рассмотрены проблемы, связанные с динамикой предоставления образовательных услуг по диверсификации в ходе повышения квалификаичии педагогических кадров в Украине, что обусловлено действием Закона Украинь «Об образовании» и постановлением Кабинета Министров Украины «Некоторые вопросы повышения квалификачии педагогических и научно-педагогических работников». Обнародованы результаты исследования, проведенного на примере конкретной административной единицьь - Основянского район г. Харькова. Обоснована важность создания отдельных модулей в пределах 30 часов (1 кредита) для формирования определенных специиальных компетенций работников образования по результатам самооценки.

Ключевые слова: диверсификачия образовательных услуг, руководитель образования, содержательныии модуль, работник образования, учитель, учреждение высшего образования, учреждение общего среднего образования.

The paper deals with the problems related to the $d y$ namics of the provision of educational services for diversification of professional development of teaching staff in Ukraine, which is conditioned by the entry into force of the Law of Ukraine "On Education» and the Cabinet of Ministers of Ukraine Resolution "Some Issues of Professional Development of Teaching and Research Staff》. The results of a study conducted on the example of an administrative unit - Kharkiv district have been published.
The study was implemented in cooperation with the Department of Creative Pedagogy and Intellectual Property of the Kharkiv City Council Department of Creative Education and the Intellectual Property Department of the Ukrainian Engineering and Pedagogical Academy with the involvement of the specialists of V.N. Karazin Kharkiv National University within the framework of scientific and research work №19-01 DB «Theoretical and methodological foundations for improving the skills of education system employees in the field of intellectual property». The importance of creating separate modules within 30 hours (1 credit) for the formation of certain special competences of teaching staff based on the results of self-assessment has been substantiated. The emphasis is placed on the formation of their special competence in the field of protection of intellectual property rights, which enhances the individual self-esteem of employees and stimulates the further innovative development of secondary education institutions. The importance of theoretical, methodological and content substantiation of individual modules material and determination of their place in the general concept of professional development within each individual program is emphasized. Particular attention is paid to the role of higher education institutions'websites in this process.

Key words: diversification of educational services, head of education, content module, teaching staff, teacher, higher education institution, secondary education institution, professional development

Постановка проблеми. Процес диверсифікації освітніх послуг із підвищення кваліфікації педагогічних працівників в Україні почав активно впроваджуватися в життя після вступу в дію Закону України «Про освіту» (2017) [2]. При цьому переважна більшість оприлюднених досліджень із даної проблематики стосується моделювання, створення організаційних механізмів і змістовного наповнення процесу підвищення кваліфікації педагогічних кадрів у нових умовах. Нами ж означена проблема розглядається з інших позицій, зокрема ми ставимо за мету на основі проведеного статистичного аналізу висвітлити тенденції на ринку освітніх послуг щодо підвищення кваліфікації на прикладі конкретної адміністративної одиниці - Основ'янського району м. Харкова, на території якого наявна низка закладів вищої освіти (далі - 3BO), що є потенційними суб'єктами підвищення кваліфікації педагогічних кадрів. 
Крім того, в дослідженні представлено погляди на формування окремих спеціальних компетентностей як учителів, так і керівників закладів освіти за модульним принципом. Особливу увагу при цьому намагатимемося приділити питанням формування спеціальної компетентності у сфері захисту прав інтелектуальної власності працівників освіти, а також довести, що іiі набуття сприятиме інноваційному розвитку закладів загальної середньої освіти (далi - 33СO).

Аналіз наукових досліджень і публікацій. Професійний розвиток та підвищення кваліфікації педагогічних і науково-педагогічних працівників висвітлено у ст. 59 Закону України «Про освіту», де зазначається, що «підвищення кваліфікації може здійснюватися за різними видами (навчання за освітньою програмою, стажування, участь у сертифікаційних програмах, тренінгах, семінарах, семінарах-практикумах, семінарах-нарадах, семінарах-тренінгах, вебінарах, майстер-класах тощо) та в різних формах (інституційна, дуальна, на робочому місці (на виробництві) тощо). Педагогічні та науково-педагогічні працівники мають право підвищувати кваліфікацію в закладах освіти, що мають ліцензію на підвищення кваліфікації або провадять освітню діяльність за акредитованою освітньою програмою. Результати підвищення кваліфікації у таких закладах освіти не потребують окремого визнання і підтвердження. Педагогічні та науково-педагогічні працівники мають право підвищувати кваліфікацію в інших суб'єктів освітньої діяльності» [2].

Деталізація вищеозначених законодавчих положень знайшла своє відображення у постановах Кабінету Міністрів України від 21.08.2019 № 800 «Деякі питання підвищення кваліфікації педагогічних і науково-педагогічних працівників» [8] та від 27.12.2019 № 1133 «Про внесення змін до Порядку підвищення кваліфікації педагогічних і науково-педагогічних працівників» [7].

У зв'язку з цим Т. М. Сорочан зауважує, що це орієнтує післядипломну педагогічну освіту не лише на традиційні для неї функції оновлення знань і вмінь, а й на розвиток професійної культури, самосвідомості педагогів, формування в них гуманістичних психологічних настанов, соціально-значущих методів професійної діяльності, посилення світоглядної, смислоутворюючої й розвивальної функцій післядипломної педагогічної освіти. Також учена наголошує, що поняття професійного розвитку та розвитку професіоналізму близькі за смислом, але при цьому під професійним розвитком варто розуміти процес, а під розвитком професіоналізму - результат. Як наслідок - у контексті професійного розвитку як процесуального складника післядипломної освіти слід розглядати умови, організацію та форми освітнього процесу, освітні технології та методики, а професіоналізм як результативний, якісний складник потребує розроблення критеріїв, показників, індикаторів, визначення рівня сформованості та розвитку [10].

Зі свого боку С. Толочко наголошує, що результати аналізу теоретичного обгрунтування необхідності модернізації компетентностей сучасного педагога на засадах компетентнісного підходу в системі післядипломної освіти України для сталого розвитку в педагогічній літературі та чинних нормативно-правових документах засвідчують, що категорія компетентності $\epsilon$ міждисциплінарною, інтегральною та розглядається в рамках філософських, соціологічних, психологічних, педагогічних, методологічних, аксіологічних та акмеологічних досліджень. При цьому професійна педагогічна компетентність виступає як сукупність загальнопедагогічних, загальнокультурних i комунікативних умінь та інтегративних якостей особистості фахівця, світоглядних і науково-професійних поглядів, педагогічної творчості та майстерності, які визначають успішність освітньої діяльності, здатність до самореалізації,саморозвитку й самовдосконалення впродовж усього життя; стійка соціальна й освітня цінність, зміст якої динамічно залежить від вимог соціальної ситуації в країні в умовах реформування в ній системи освіти [11].

Зважаючи на специфіку післядипломної педагогічної освіти, Ю. Каліночкіна у колективній монографії зазначає, що висуваються високі вимоги до професіоналізму викладача й ефективності технологій навчання. Відбувається модернізація системи підвищення кваліфікації та методичного супроводу педагогічної діяльності що забезпечує підвищення якості роботи, поповнення банку інноваційних методик, адаптованих до умов регіону, сприяє залученню ресурсу інших освітніх установ та організацій, створенню методичних центрів в об'єднаних територіальних громадах, налагодженню процесу формування й поширення передових управлінських і педагогічних практик. У центрі цієї роботи - забезпечення освітнього процесу відповідно до нових Державних стандартів та реалізації проєкту Нової української школи, при цьому ключовою умовою $\epsilon$ високий рівень компетентностей управлінських і педагогічних кадрів [6].

У процесі проєктування курикулуму підвищення кваліфікації педагогічних працівників, наголошує М. Скрипник, слід ураховувати: зміни в сучасній постнеокласичній науці, основою якої стає синтез гуманітарних та науково-раціональних стратегій; методологічні знання про суспільство, природу наукового пізнання, способи педагогічної діяльності; досвід здійснення відомих загальнолюдських способів діяльності та способів організації науково-педагогічної діяльності; досвід творчої науково-педагогічної діяльності з розв'язання інноваційних проблем, що виникають перед суспільством та його освітньою інституцією; досвід ціннісного ставлення до культури, світу, особистості, людства, що зумовлює формування науково-педагогічної свідомості тощо [9]. У цьому форматі актуальним також вважаємо дослідження Ю. Завалевського, в якому висвітлюється формування конкурентоспроможності вчителя в контексті його інноваційно-професійної діяльності [1].

Питання обгрунтування необхідності подальшого розвитку системи управління післядипломною педагогічною освітою через модернізацію положень методології означеної галузі освіти та оновлення функцій у контексті подолання недоліків,притаманних професійній діяльності вчителів розглядає В. Швидун. Він, зокрема, звертає увагу на необхідності формування такої системи самоосвіти на основі реалізації післядипломною педагогічною освітою своїх координуючо-організаційних функцій, які підказує сама освітня практика [12].

Загалом проблеми формування компетентностей як учителя, так і керівника освіти висвітлено в роботах Л. Даниленко, Г. Єльникової, Ю. Завалевського, В. Кременя, Г. Кравченко, Н. Кравчук, О. Локшиної, В. Лунячека, О. Ляшенка, О. Мармази, В. Олійника, О. Пометун, Н. Рубан, Н. Фесенко О. Савченко та інших науковців.

Водночас проведений аналіз свідчить, що в сучасній джерельній базі за окресленим нами напрямом педагогічних досліджень недостатньо висвітлено проблеми формування окремих спеціальних 
компетентностей працівників освіти (зокрема компетентності у сфері захисту прав інтелектуальної власності), що і сприяло написанню означеної статті.

Мета статті - проаналізувати динаміку впровадження освітніх послуг із підвищення кваліфікації вчителів в умовах диверсифікації даного процесу; обгрунтувати включення до даного процесу модулів, що дозволяють сформувати в учителя компетентність у сфері інтелектуальної власності як складової інноваційного розвитку закладу загальної середньої освіти.

Виклад основного матеріалу. Процес диверсифікації послуг із підвищення кваліфікації педагогічних працівників актуалізував розробку окремих педагогічних технологій, спрямованих на формування в учителів і керівників освіти спеціальних компетентностей. Означене питання висвітлено також у Концепції Нової української школи, де основну увагу закцентовано на базові компетентності вчителя початкових класів: професійно-педагогічну; соціально-громадянську; загальнокультурну; мовно-комунікативну; психологічно-фасилітативну; підприємницьку; інформаційно-цифрову [3].

Представлені у нашій роботі матеріали $\epsilon$ результатом співпраці Управління освіти адміністрації Основ'янського району Харківської міської ради та кафедри креативної педагогіки та інтелектуальної власності Української інженерно-педагогічної академії у межах НДР № 19-01 ДБ «Теоретико-методичні засади підвищення кваліфікації працівників системи освіти у сфері інтелектуальної власності».
У процесі проведення дослідження було поставлено завдання з'ясувати на прикладі окремого адміністративного району в межах великого міста динаміку процесів диверсифікації освітніх послуг працівникам освіти за період після вступу в дію Закону України «Про освіту» (2017) [2]. 3 цією метою серед закладів загальної середньої освіти Основ'янського району м. Харкова (на території якого розташовано 11 таких закладів) було проведено аналіз інформації (включно із 2015/2016 по 2019/2020 навчальні роки) щодо суб' єктів надання освітніх послуг із підвищення кваліфікації, до яких зверталися працівники освіти Основ'янського району.

Суб'єктами підвищення кваліфікації разом із Харківською академією неперервної освіти (далі - KBH3 «XAHO»), яка в наявній сьогодні в Україні структурі післядипломної педагогічної освіти - це обласний інститут післядипломної педагогічної освіти, $є$ Харківський національний університет імені В. Каразіна, Харківський національний педагогічний університет імені Г. Сковороди, Українська інженерно-педагогічна академія, К3 «Харківська гуманітарно-педагогічна академія» Харківської обласної ради.

У процесі проведення дослідження було з'ясовано, що сьогодні спостерігається чітка тенденція до отримання освітніх послуг учителями і керівниками освіти в різних суб'єктів цього процесу, появу якої відзначають саме після початку 2017/2018 навчального року. Відповідна інформація наведена нами у таблиці 1 та на рисунках 1, 2.

Таблиця 1

Динаміка процесів диверсифікації послуг щодо підвищення кваліфікації працівників освіти на прикладі Основ'янського району м. Харкова

\begin{tabular}{|c|c|c|c|c|c|c|c|c|c|c|}
\hline \multirow{3}{*}{$\begin{array}{c}\text { Суб'скти підвищення } \\
\text { кваліфікації }\end{array}$} & \multicolumn{10}{|c|}{ Навчальний рік } \\
\hline & \multicolumn{2}{|c|}{$2015 / 2016$} & \multicolumn{2}{|c|}{$2016 / 2017$} & \multicolumn{2}{|c|}{$2017 / 2018$} & \multicolumn{2}{|c|}{$2018 / 2019$} & \multicolumn{2}{|c|}{$2019 / 2020$} \\
\hline & $\mathbf{y}$ & $\mathbf{K}$ & $\mathbf{y}$ & $\mathbf{K}$ & $\mathbf{y}$ & $\mathbf{K}$ & $\mathbf{y}$ & $\mathbf{K}$ & $\mathbf{y}$ & $\mathbf{K}$ \\
\hline КВH3 «XAHO» & 105 & 2 & 105 & 4 & 86 & 9 & 76 & - & 27 & - \\
\hline ХНУ імені В. Каразіна & - & - & 6 & - & 4 & 3 & 13 & 1 & 12 & - \\
\hline $\begin{array}{c}\text { ХНПУ імені } \\
\text { Г. Сковороди }\end{array}$ & - & - & - & - & 1 & & 1 & - & 2 & - \\
\hline УІПА & - & - & - & - & - & - & - & 2 & 2 & - \\
\hline КЗ «ХГПА» ХОР & - & - & - & - & - & - & - & - & - & - \\
\hline Інше & - & - & - & - & - & - & - & - & - & - \\
\hline Усього & 105 & 2 & 111 & 4 & 91 & 12 & 90 & 3 & 49 & \\
\hline
\end{tabular}

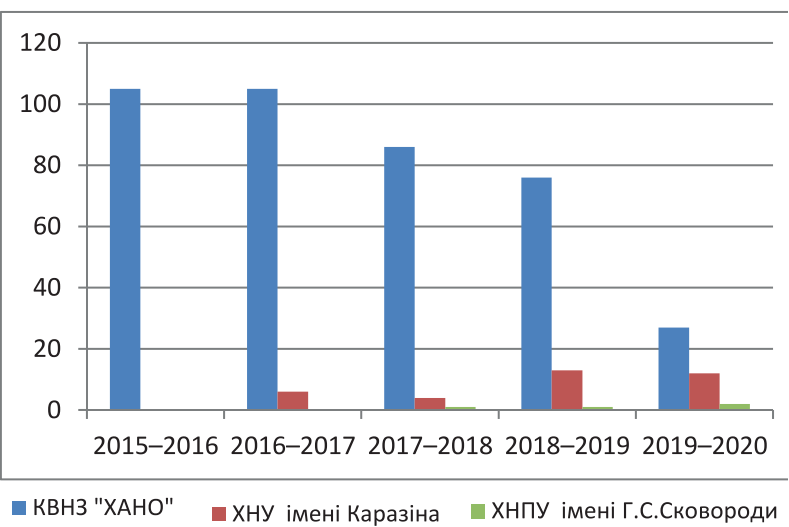

Рис. 1. Динаміка процесу диверсифікаиії освітніх послуг щчодо підвищення кваліфікації вчителів на прикладі Основ'янського району м. Харкова

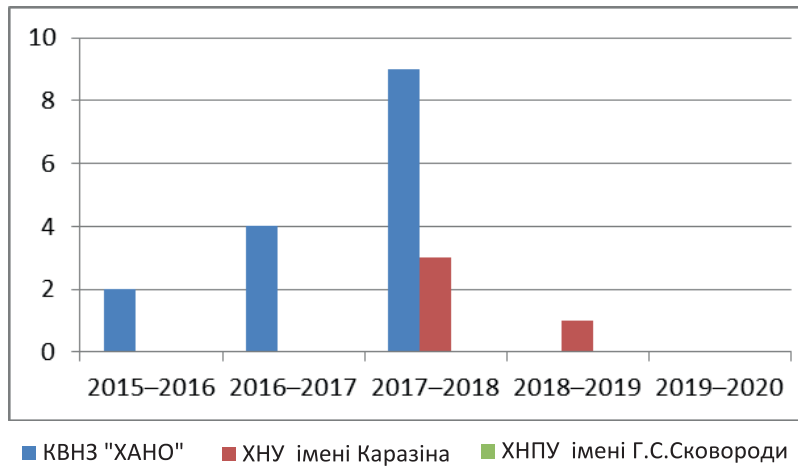

Рис. 2. Динаміка прочесу диверсифікації освітніх послуг щуодо підвищення кваліфікаиї̈ керівників освіти на прикладі Основ'янського району м. Харкова 
Проведений аналіз свідчить, що Закон України «Про освіту» (2017), з одного боку, став каталізатором процесів диверсифікації послуг із підвищення кваліфікації педагогічних кадрів, а 3 іншого, - довів, що означені процеси розвиваються надто повільно. На нашу думку, це обумовлено не лише ментальністю вітчизняної освітянської спільноти, а й низькою поінформованістю педагогів щодо сучасних можливостей ринку відповідних освітніх послуг. У зв'язку 3 цим і вчителі, і керівники освіти сьогодні не відчувають себе повною мірою суб'єктами підвищення кваліфікації, що дає можливість впливати на індивідуальну освітню траєкторію.

При цьому в умовах диверсифікації послуг щодо підвищення кваліфікації педагогічних кадрів актуалізується потреба у створенні окремих модулів підвищення кваліфікації, що мають вузьку спрямованість на формування певних спеціальних компетентностей педагогічних працівників та покликані сприяти подальшому інноваційному розвитку закладів освіти. Однією 3 таких компетентностей як у контексті інноваційного розвитку України загалом, так і кожного окремо взятого закладу освіти зокрема $є$ компетентність у сфері інтелектуальної власності.
За результатами опитування, проведеного фахівцями кафедри креативної педагогіки та інтелектуальної власності разом із спеціалістами соціологічного факультету ХНУ імені В. Каразіна у межах НДР № 19-01 ДБ «Теоретико-методичні засади підвищення кваліфікації працівників системи освіти у сфері інтелектуальної власності», було з'ясовано, що на запитання "Чи зацікавлені ви у підвищенні кваліфікації щзодо захисту прав інтелектуальної власності, правил академічної етики?» позитивно відповіли 52\% респондентів, незацікавленими виявилися $27 \%$, не змогли чітко сформулювати свою позицію 21 \% опитаних учителів.

Завдяки роботі, проведеній із працівниками освіти Основ'янського району м. Харкова, було доведено, що інтелектуальний продукт, який вони генерують, повинен бути захищений у межах наявної нормативно-правової бази та за певних умов може бути предметом комерційного чи некомерційного трансферу технологій.

Для формування відповідної спеціальної компетентності вчителям було запропоновано науково-практичні семінари із таких тем: «Продукти інноваційної діяльності вчителя як об'єкти інтелектуальної власності», «Академічна доброчесність».

Зі змістовим наповненням представлених вище семінарів можна ознайомитися у таблицях 2,3 .

Таблиия 2

Робоча програма науково-практичного семінару

«Продукти інноваційної діяльності вчителя як об’єкти інтелектуальної власності»

\begin{tabular}{|c|l|c|}
\hline $\begin{array}{c}\text { № } \\
\text { 3/п }\end{array}$ & \multicolumn{1}{|c|}{ Тема } & $\begin{array}{c}\text { Кількість } \\
\text { годин }\end{array}$ \\
\hline 1 & Основні аспекти Закону України «Про авторське право і суміжні права» & 2 \\
\hline 2 & $\begin{array}{l}\text { Продукти інтелектуальної, творчої праці працівників закладів освіти як об’єкти авторського } \\
\text { права }\end{array}$ & 2 \\
\hline 3 & Об'єкти промислового права в сфері діяльності працівників закладів освіти & 2 \\
\hline Усього & $\mathbf{6}$ \\
\hline
\end{tabular}

Таблиия 3

Робоча програма науково-практичного семінару «Академічна доброчесність»

\begin{tabular}{|c|l|c|}
\hline $\begin{array}{c}\text { № } \\
\text { 3/п }\end{array}$ & \multicolumn{1}{|c|}{ Тема } & $\begin{array}{c}\text { Кількість } \\
\text { годин }\end{array}$ \\
\hline 1 & Академічна доброчесність & 2 \\
\hline 2 & Академічна відповідальність за порушення принципу доброчесності & 2 \\
\hline 3 & Практична робота. Розробка положення закладу освіти «Про академічну доброчесність». & 2 \\
\hline Усього & $\mathbf{6}$ \\
\hline
\end{tabular}

У разі потреби змістове наповнення представлених семінарів можна розширити до 30 годин (1 кредит), перетворивши на складову системного процесу підвищення кваліфікації в межах законодавчо обумовлених 150 годин за п’ять років.

При цьому варто наголосити, що, зважаючи на постанову КМ України від 21.08.2019 № 800 «Деякі питання підвищення кваліфікації педагогічних і науково-педагогічних працівників», «педагогічні та науково-педагогічні працівники 3 урахуванням результатів самооцінки компетентностей і професійних потреб, змісту власної викладацької діяльності та/або посадових обов'язків самостійно обирають конкретні форми, види, напрями та суб'єктів надання освітніх послуг із підвищення кваліфікації» [2]. Отже, на нашу думку, цільову аудиторію для формування компетентності у сфері інтелектуальної власності потрібно підбирати за певним алгоритмом.
Означена компетентність передусім повинна бути сформована в учителів і керівників освіти, які активно розвиваються та є суб'єктами інноваційної діяльності у своїх 33СО. Даний процес передбачає такі основні етапи:

1. Формування в закладі освіти групи педагогічних працівників, які створюють нові розробки та $\epsilon$ носіями певного передового педагогічного досвіду тощо.

2. Проведення зустрічей із цільовою аудиторією педагогічних працівників з метою роз'яснення поточної ситуації, залучаючи фахівців із захисту прав інтелектуальної власності та розвитку освітніх інновацій.

3. Формування групи педагогічних працівників, які виявили бажання підвищити свою кваліфікацію у сфері захисту прав інтелектуальної власності.

4. Підписання договору із суб'єктом надання відповідних освітніх послуг (як правило - профільною кафедрою певного ЗВО). 
5. Отримання освітньої послуги.

6. Оцінювання результатів підвищення кваліфікації (може передбачати отримання педагогічними працівниками авторських свідоцтв та інших документів).

Таким чином, варто зауважити, що оволодіння спеціальною компетентністю у сфері інтелектуальної власності не лише підвищить самооцінку працівника освіти, а й стимулюватиме його особистісний розвиток як суб'єкта інноваційного процесу.

На рисунках 3, 4 пропонуємо ознайомитися із вебсайтом, розробленим фахівцями кафедри креативної педагогіки та інтелектуальної власності Української інженерно-педагогічної академії, що спрямований на отримання інформації щодо підвищення кваліфікації у сфері інтелектуальної власності.

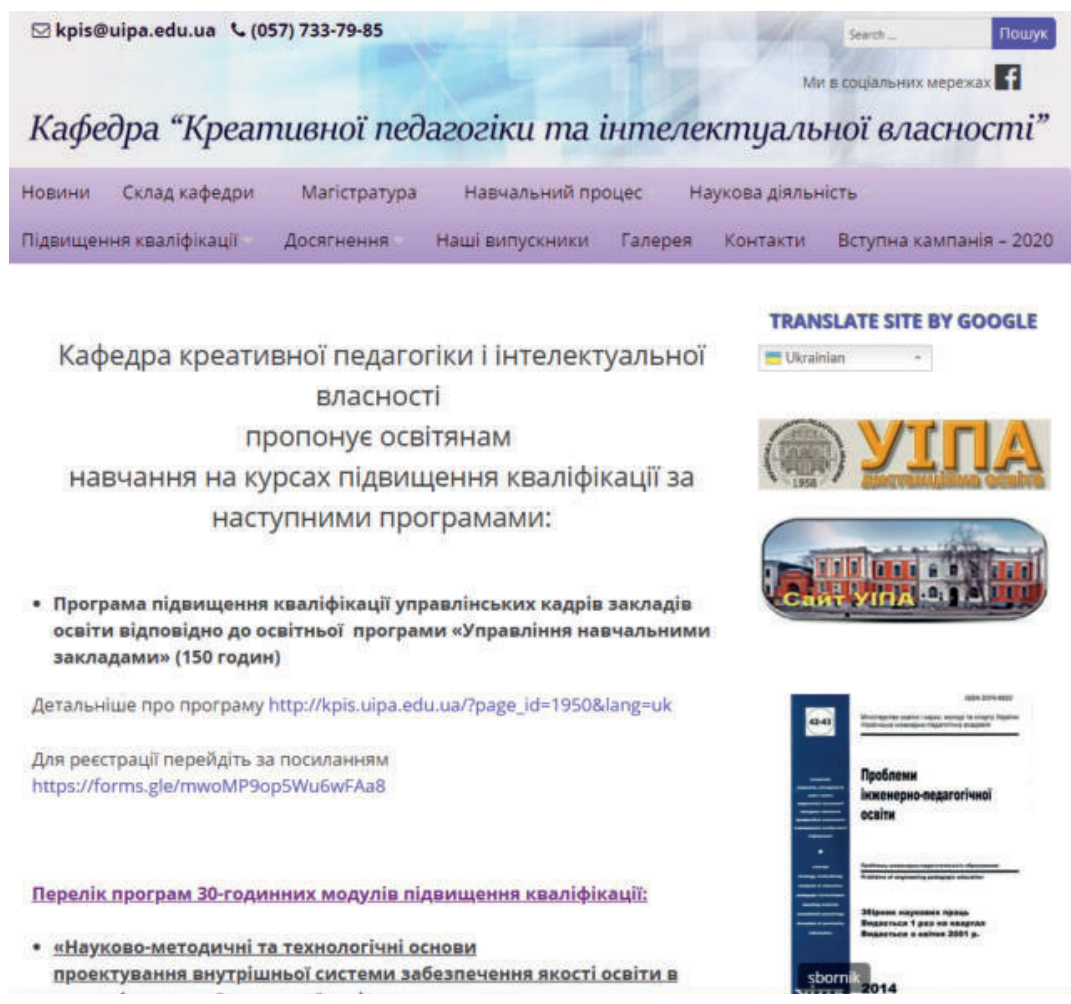

Рис. 3. Сторінка сайту кафедри креативної педагогіки та інтелектуальної власності УІПА, спрямована на надання послуг щуодо підвищення кваліфікації пращівників освіти

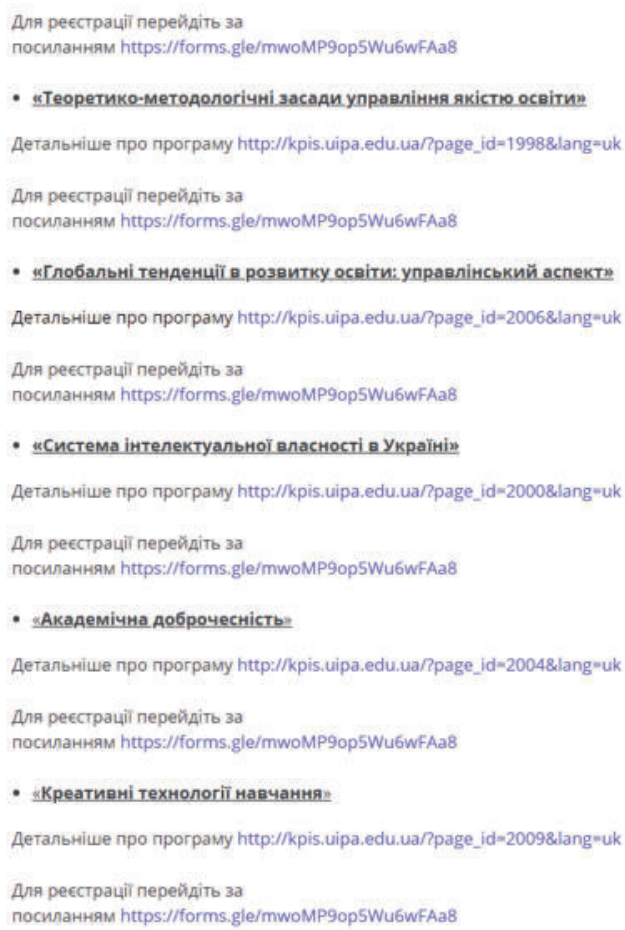

Рис. 4. Окремі модулі щуодо підвищення кваліфікації працівників освіти (зокрема й у сфері інтелектуальної власності), представлені на сайті кафедри креативної педагогіки та інтелектуальної власності УІПА 
Використання означених вище модулів створює сприятливі умови для побудови індивідуального плану підвищення кваліфікації педагогічного працівника за блочно-модульною системою.

Отже, зважаючи на результати, представлені нами у дослідженні, можемо зробимо такі висновки:

1. Процеси диверсифікації освітніх послуг щодо підвищення кваліфікації працівників освіти перебувають сьогодні на початковому етапі та мають незначну позитивну динаміку.

2. Широка освітянська спільнота на сучасному етапі не відчуває себе повноцінним суб'єктом підвищення кваліфікації та має певні проблеми з побудовою індивідуального профілю власного професійного розвитку.

3. Важливим аспектом подальшого розвитку процесів підвищення кваліфікації педагогічних кадрів створення певних цільових модулів, спрямованих на формування окремих спеціальних компетентностей у споживачів освітніх послуг (зокрема компетентності у сфері інтелектуальної власності).

4. Формування компетентності педагогічних працівників у сфері інтелектуальної власності не лише спонукає їх до подальшого особистісного розвитку, а й стає каталізатором інноваційного розвитку закладів загальної середньої освіти.

5. Ключову роль в інформуванні педагогічних працівників щодо можливості отримувати освітні послуги із підвищення кваліфікації за індивідуальною програмою відіграють вебсайти закладів освіти, що $\epsilon$ суб'єктами підвищення кваліфікації. Однак такі сайти потребують певного вдосконалення, наприклад, зовнішні посилання на них повинні бути пов'язані із вебсайтами закладів загальної середньої освіти 3 метою покращення процесу пошуку споживачами відповідної інформації.

Перспективним напрямом подальших наших досліджень із даної проблематики є теоретико-методичне та змістовне обгрунтування низки окремих модулів, що стосуються підвищення кваліфікації педагогічних кадрів та спрямовані на формування певних спеціальних компетентностей працівників закладів освіти.

\section{СПИСОК ВИКОРИСТАНОЇ ЛІТЕРАТУРИ}

1. Завалевський Ю. І. Теоретико-методичні засади формування вчителя як конкурентно спроможнного фахівця : монографія / Ю. І. Завалевський. - Чернівці : Букрек, 2014. - 416 с.

2. Закон України «Про освіту» від 05.09.2017 № 2145-VIII. URL: https://zakon.rada.gov.ua/laws/ show/2145-19/stru (дата звернення: 18.12.2019).
3. Концепція «Нова українська школа». URL: https:// www.kmu.gov.ua/storage/app/media/reforms/ukrainskashkola-compressed.pdf (дата звернення: 18.12.2019).

4. Лунячек В. Е. Захист об'єктів інтелектуальної власності в закладах загальної середньої освіти: проблеми на сучасному етапі / В. Е. Лунячек, Н. Л. Кравчук // Проблеми інженерно-педагогічної освіти : зб. наук. пр. - Х. : Українська інженерно-педагогічна академія, 2019 - Вип. 62. - С. 36-45.

5. Лунячек В. Е. Формування компетентності працівників закладів загальної середньої освіти у сфері інтелектуальної власності в процесі підвищення кваліфікації / В. Е. Лунячек, Н. П. Рубан // Проблеми інженерно-педагогічної освіти : зб. наук. пр. - Х. : Українська інженерно-педагогічна академія, 2019 Вип. 63. - С. 16-29.

6. Післядипломна педагогічна освіта в умовах децентралізації та модернізації: регіональний аспект : монографія / за заг. ред. В. С. Береки. - Хмельницький : ФОП Мельник А.А., 2017. - 548 с.

7. Постанова Кабінету Міністрів України «Про внесення змін до Порядку підвищення кваліфікації педагогічних і науково-педагогічних працівників» від 27.12.2019 № 1133 URL: https://zakon.rada.gov. ua/laws/show/1133-2019-\%D0\%BF(дата звернення: 20.12.2019).

8. Постанова Кабінету Міністрів України від 21.08.2019 № 800 «Деякі питання підвищення кваліфікації педагогічних і науково-педагогічних працівників». URL: https://zakon.rada.gov.ua/laws/show/ 800-2019-\%D0\%BF (дата звернення: 20.12.2019).

9. Скрипник М. Закономірності та принципи формування змісту підвищення кваліфікації педагогічних працівників в проектованому курикулуму / М. Скрипник // Адаптивне управління: теорія і практика. - 2017. - № 3 (5). - (Серія «Педагогіка»). URL: //http://am.eor. in.ua/images/adapt/Vol.3ped5/17ped3_5skrypnik_r.pdf (дата звернення: 20.12.2019).

10. Сорочан Т. М. Феномен педагогічної майстерності як методологія трансформації професіоналізму педагогів Нової української школи / Т. М. Сорочан // Педагогіка і психологія. - 2019. - № 1 (102). - С. 5-13.

11. Толочко С. Модернізація компетентнісного підходу в системі післядипломної педагогічної освіти України для сталого розвитку освіти / С. Толочко // Нова педагогічна думка : науково-методичний журнал. - 2018. - № 3 (95). - С. 29-36.

12. Швидун В. М. Управління післядипломною педагогічною освітою як складовою освіти в Україні / В.М.Швидун // Нова педагогічна думка : науково-методичний журнал. - 2019. - № 3 (99). - С. 48-51.

Дата надходження до редакиї: 24.01.2020 p. 